\title{
本邦產主要フジッボ類幼生の查定について
}

\author{
本 野 禮 次 郎 \\ (東 大 農 学 部)
}

\section{On the Rearings and Metamorphoses of Four Important Barnacles in Japan}

By

\section{Reijiro Hirano}

\begin{abstract}
The larvae of four important barnacles in Japan, that is, Balanus amphitrite communis, Balanus trigonus, Balanus tintinnabulum rosa and Tetraclita sqamosa were reared in the laboratory. As their foods the artificially cultured marine plankton diatom, Skeletonema costatum, were given.

Barnacles passed through seven nauplius stages in their development from the egg to the cypris stage. The number of spines of the 1st appendage can be used as the standard in discriminating each naupius stage, because the increase of number occurs regularly during development.

As the key to classify the species of these nauplii, the structural variations in their caudal horns and basipodites of the 2 nd appendages are distinguishable.
\end{abstract}

\section{1. 緒言}

フツジボ類の浮遊幼生期については, 従来 Balanus crenatus (Herz, 19331)), シロ スジフジツボ Balanus amphitrite albicostatus (石田, 八杉, 19372)), タテジマフジッ ボ Balanus amphitrite hawaiiensis (藤永, 笠原, 19423)) の三種類について, その変 態過程が観察されているにすぎない。而もこの中で前二者の観察には不充分な点が少くな く現在フジツボのノープリウス幼生の査定は殆ど不可能な状態にある。しかしこの浮遊幼 生期の全過程を明かにすることは，単にフジッボによる附着害の防止上必要であるだけで なく,ノープリウス幼生が明確な沿岸起源の幼生プランクトンとして査定じ得れば, 沿岸 水塊の移動, 水塊自身の生物的環境としての状態等を示唆するものとして, 海洋生物学上 大きな意義をもつと考えられる。

筆者は195C-1952年の間, 神奈川県三崎町東大臨海実験所に於て, フジツボ類数種の幼 生を飼育して変態過程を明かにすることが出来たので，こ〉にその概要を報告する。

2. 飼育

今回飼育観察したのは, タテジマ, シロスジの他にサラサ Balanus amphitrite communiș, サンカク Balanus trigonus, クロ Tetraclita sqamosa, アカ Balanus tintinnabulum rosa の四種のフジツボで, いずれもわが国近海でもつとも普通にみられるもの 
である。

材料, 容器：成体の mantle cavity よりとり出した成熟卵を, あらかじめ海水を充 たして置いた硝子容器中に入れると, 多数のノープリウス幼生が卵孚化してくる。ノープリ ウスは正の趨光性を有するので, これを利用して容器中の一ヶ所に集め, 駒込ピペットで 静かに飼育用ビーカーに移して実験に供した。飼育用ビーカーとしては， $1 \mathrm{~L}$ のものを用 いこれに約 5000〜8000 のノープリウスを収容した。

飼育用海水, 温度：海水は salinity $25 \sim 35 \%$ のものを瀘過して用い, 飼育中, 換 水を行う場合には同一海水を使用した。飼育は一定温度を保つために, 恒温槽の中で行つ た。フジツボは種類により附着適温を異にする4)が，飼育水温もこれに一致するように調 節した。

餌料：餌としては培養珪藻 Skeletonema costatum を多量に与えた。フジツボ幼生 の慨として重要なのは, その浮遊性と大きさの 点であるが径 5 ～15 $\mu$ のものが最適であ つた。

\section{3. 変 態}

脱皮回数：ノープリウスはいずれの種類も 7 回の脱皮変態を経てシプリス幼生にな つた。これに要した期間は 5〜1 日であつた。フジツボのノープリウス期については，こ れまでいろいろの説があり5)，とくに6 期説が多く唱えられているが，これらは殆ど採集 によつて各 stage をつなぎ合わせたものなので疑問の点が多く，再検討の余地があるよう に思われる。

附属肢の変化： 3 対の附属肢はノープリウスが脱皮するにつれて, その棘数が増加し ていくが，とくに第一附属肢の棘は脱皮毎に規則正しくその数が増加していくので, ノ一 プリウス幼生の期の検索に用いることが出来る。第 1 表にみられる如く，2 期以后は脱皮

Table 1. The number of spines on the first appendage and on exopodites of the second and third appendages.

\begin{tabular}{|c|c|c|c|}
\hline Stage & 1st Appendage & Ex. 2nd Appendage & Ex. 3rd Appendage \\
\hline I & 8 & 5 & 4 \\
II & 8 & 7 & 5 \\
III & 9 & 7 & 5 \\
IV & 10 & 9 & 5 \\
V & 12 & 11 & 6 \\
VI & 13 & 12 & 6 \\
VII & 13 & 12 & 6 \\
\hline
\end{tabular}

毎に 1 棘宛増加していくが，4 期から 5 期に変態するときには 2 棘新生する。このときは 体長の成長率からみても著しい成長を示し (平野. 未発表), フジツボのノープリウス期はこ こを境として 2 つの circle に分けて考えるのが妥当であろう。同様なことがカキの幼生 
遊泳期についても予想されている6゙が，この点は幼生プランクトンの 飼育と関連して興味 深い。

体軀の変化：第 1 期ノープリウスでは, carapace の両側にある frontal horn は後 方に熱曲し thoracoabdominal process ああまり発達していないが, 2 期以后, frontal hornは体の長軸に対して直角に伸長し, thoracoabdominal process も発達して先端は叉 状に分岐する。 4 期には carapace の後縁に 1 対の caudal horn を生じ，第 7 期には nauplius eye の左右に複眼がみられる。

\section{4. 種の查定, 娭索表}

前述の如くノープリウス幼生の期の検索には, 主として第 1 附属肢の棘数の変化が用 いられる。

それぞれの種のノープリウス間の相違は, caudal horn を生ずる 4 期以后に於て判然 としてくる。すなわち, まず caudal horn の形態的差異によつて Balanus amphitrite に属する三つの変種とそれ以外のものとに分けられる。更に各 group の中に於ける種の 查定は第 2 附属肢の basipodite の形態的差異により行われる。第 2 附属肢の basipodite はよく分化しているが，2 期以后各 stage を通じて殆ど変化がみとめられない。この basipodite は第 3 附属肢の endopodite の基部と共に慨を聆る働きをしていると考えられ るが, これが脱皮変態によつても恋化しないことは, 全ノープリウス期を通じて食性が殆 ど変らないことを示していると考えて差支えないであろう。

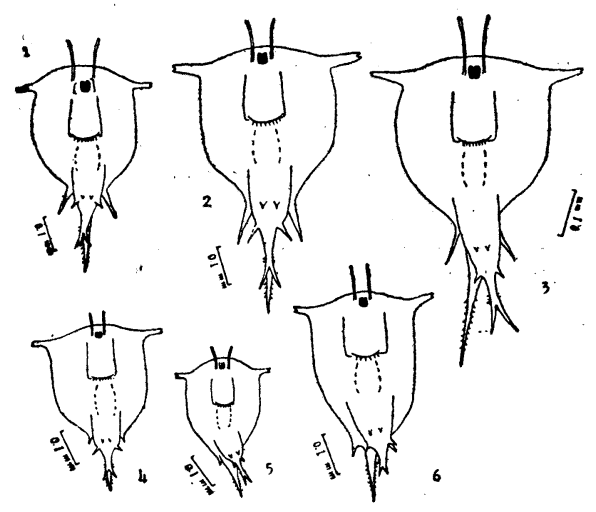

Fig. 1. Nauplii of barnacles (4th stage).
1. Balanus trigonus
2. Balanus tintinnabulum rosa
3. Tetraclita sqamosa
4. Balanus amphitrite albicostatus
5. Balanus amphitrite hawaiiensis
6. Balanus amphitrite communis

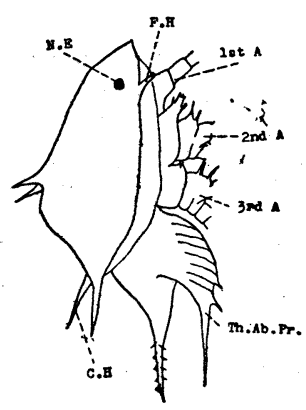

Fig. 2. Side view of nauplius: of Balanus tintinnabulum rosa (4th stage).

F.H. Frontal Horn 1st A 1st Appendage 2nd A 2nd Appendage 3rd A 3rd Appendage Th.Ab.Pr. Thoraco-Abdominal Process

C.H Caudal Horn N.E Nauplius Eye 


\section{期の娭索}

I. 第 1 附属肢に 8 束

i. frontal horn は後方に禁曲 附属肢の束に岡毛なし

……第 1 期

ii. frontal horn は側方に伸長 附属肢の若干に剛毛を生ず sensory appendage を生ず

……第 2 期

II. 第 1 附属肢に 9 棘 …...第 3 期

III. 第 1 附属肢に 10 棘

caudal horn を生ず

……第 4 期

IV. 第 1 附属肢に 12 棘 …...第 5 期

V. 第 1 附属肢に 13 棘

i. 腹節に 6 対の小欶を生ず

……第 6 期

ii. 1 対の複眠を生ず.......第 7 期

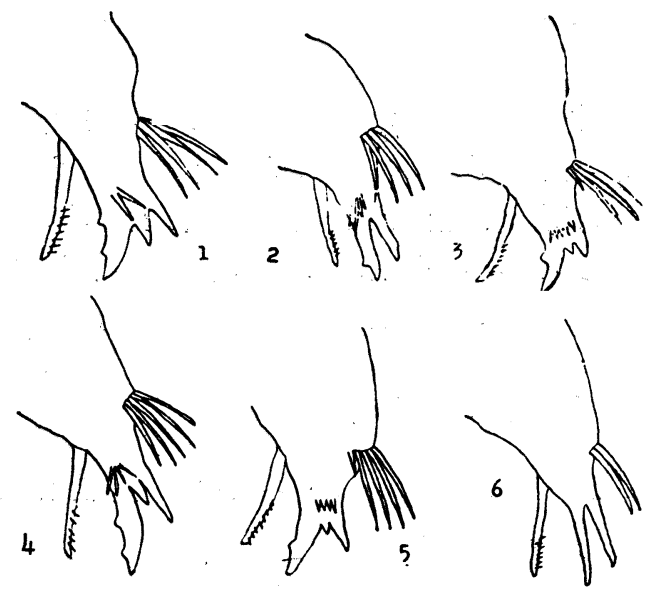

Fig. 3. Basipodite of second appendage in each species.

1. Tetraclita sqamosa

2. Balanus amphitrite albicostatus

3. Balanus amphitrite communis

4. Balanus trigonus

5. Balanus tintinnabulum rosa

6. Balanus amphitrite hawaiiensis

\section{種の查定}

(1). thracoabdominal process はあまり発達せず, caudal horn は frontal horn に 比し遙かに短小

frontal horn は体の長軸に対し稍々斜前方に伸長しその先端は carapace の前縁と同 じ線か或はそれより前方にある。第 2 附属肢脚基の先端は 3 本に分岐し 5 棘あり

......Balanus amphitrite communis

(2). frontal horn は体の長軸に対し略々直角, 第 2 附属肢脚基の先端は 2 本に分岐…(3) 第 2 附属肢脚基の棘は 5 本...................................Balanus amphitrite albicostatus

(3). 第 2 附属㬵脚基の棘は 3 本

Balanus amphitrite hawaiiensis

(4). thoracoabdominal process はよく発達し, caudal horn は frontal horn と同等 或はそれ以上に伸長する。

第 2 附属肢脚基の先端は 3 本に分岐

carapace 背部の略々中央に 1 対の horn が有り，第 2 附属肢脚基には 6 束

-.....Balanus tintinnabulm rosa

(5). carapace 背部は平滑

第 2 附属肢脚基に 6 束束

Balanus trigonus

第 2 附属肢脚基に 5 棘 Tetraclita sqamosa 
5. 要 約

1. サンカク, サラサ, クロ, アカの 4 種のフジツボについて培養珪藻 Skeletonema costatum を慨として，そのノープリウス幼生の人工飼育を行つた。

2.ノープリウスはいずれも 7 回の脱皮を経てシプリス幼生となる。これに要する期: 間は5〜10日である。

3. フジツボのノープリウス幼生の期の検索には, 第 1 附属肢の棘数の変化が用いら れ, 種の査定は caudal horn 及び第 2 附属肢 basipodite の形態的差異により行われる。

終りに本研究に対し終始懇篤なる御指導を賜つた松江吉行教授, 笠原昊博士及び御便 宜を戴いた大串順氏に厚く感謝致します。

\section{引用文 献}

1) Herz, L.E., 1933. Biol. Bull., 64.

2）石田，八杉，1937：植物及動物 5, 9.

3）藤永, 笠原, 1942: 動雑, 54, 3.

4) 平野, 大串, 1952: 日水誌, 18, 11 .

5) Weiss, C.M., 1948: Biol. Bull., 94.

6）今井, 畑中, 1949 : 農研彙報, 1, 1. 